Edited by Doug Reeve, Donald N. Dewees, and Bryan W. Karney

In Ontario, electricity has traditionally been generated from hydroelectric facilities, coal, and nuclear power. Today the province must respond to the escalating demand for electricity, coupled with an aging infrastructure and diminishing capacity, while also addressing growing concerns about air pollution, global warming, and the environmental impact of fossil fuel combustion. Sources of hydroelectric power in the province are limited, while nuclear power is expensive and raises safety concerns. Power from green energy sources, such as the sun and wind, is also costly to produce and in some cases is intermittent. Electricity policy in Ontario thus requires the careful balancing of environmental goals and values against costs that must be borne by consumers and taxpayers.

Current Affairs brings together local and international experts on energy, the environment, and public policy to discuss the major electricity policy issues facing Canada's most populous and industrial province. The contributors, who represent academia, think tanks, consulting firms, governments, and the International Energy Agency, bring fresh perspectives and a wealth of experience to the substantive questions concerning Ontario's electricity future. Collectively they suggest that in Ontario, as in other jurisdictions, environmental policy must be connected to meaningful research, public dialogue, and solid educational and regulatory programs to support the behavioural and institutional changes that will lead to a sustainable electricity future.

DOUG REEVE is a professor and chair of the Department of Chemical Engineering and Applied Chemistry at the University of Toronto.

DONALD N. DEWEES is a professor in the Department of Economics at the University of Toronto.

BRYAN W. KARNEY is chair of the Division of Environmental Engineering and Energy Systems and a professor in the Department of Civil Engineering at the University of Toronto. 
This page intentionally left blank 


\section{CURRENT AFFAIRS}

\section{Perspectives on Electricity Policy for Ontario}

Edited by Doug Reeve, Donald N. Dewees, and Bryan W. Karney

UNIVERSITY OF TORONTO PRESS Toronto Buffalo London 
(C) University of Toronto Press Incorporated 2010

Toronto Buffalo London

www.utppublishing.com

Printed in Canada

ISBN 978-1-4426-4019-1 (cloth)

ISBN 978-1-4426-0994-5 (paper)

(\$)

Printed on acid-free, $100 \%$ post-consumer recycled paper with vegetable-based inks.

\section{Library and Archives Canada Cataloguing in Publication}

Current affairs : perspectives on electricity policy for Ontario / edited by Doug Reeve, Donald N. Dewees, and Bryan W. Karney.

Includes bibliographical references.

ISBN 978-1-4426-4019-1 (bound). - ISBN 978-1-4426-0994-5 (pbk.)

1. Electric power - Ontario. 2. Electric utilities - Government policy -

Ontario. 3. Electric power - Environmental aspects - Ontario. I. Reeve, Doug II. Dewees, Donald N., 1941- III. Karney, Bryan William, 1957HD9685.C3C87 $2010 \quad$ 333.793'21509713 C2009-906820-6

University of Toronto Press acknowledges the financial assistance of the Canada Council for the Arts and the Ontario Arts Council to its publishing program.

Canada Council Conseil des Arts for the Arts

du Canada

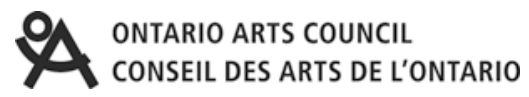

University of Toronto Press acknowledges the financial support of its publishing activities by the Government of Canada through the Book Publishing Industry Development Program (BPIDP). 